La Revue

des Droits

de l'Homme

\section{La Revue des droits de l'homme}

Revue du Centre de recherches et d'études sur les droits fondamentaux

16 | 2019

Revue des droits de l'homme - $\mathrm{N}^{\circ} 16$

\title{
What engages? The sociology of justifications, conventions, and engagements, meeting norms
}

Laurent Thévenot

\section{(2)enEdition}

\section{Journals}

Electronic version

URL: http://journals.openedition.org/revdh/7114

DOI: 10.4000/revdh.7114

ISSN: 2264-119X

\section{Publisher}

Centre de recherches et d'études sur les droits fondamentaux

\section{Electronic reference}

Laurent Thévenot, «What engages? The sociology of justifications, conventions, and engagements, meeting norms », La Revue des droits de l'homme [Online], 16 | 2019, Online since 03 July 2019, connection on 08 July 2020. URL : http://journals.openedition.org/revdh/7114 ; DOI : https://doi.org/ $10.4000 /$ revdh.7114

This text was automatically generated on 8 July 2020 .

Tous droits réservés 


\title{
What engages? The sociology of justifications, conventions, and engagements, meeting norms
}

\author{
Laurent Thévenot
}

1 In parallel with the chapter of this book in which Véronique Champeil-Desplats introduces the conceptual shifts that took place in the ways law grasps a variety of modes of normativity, this chapter outlines the sociology of justifications, conventions, and engagements that has, for its part, renewed the approach of normativity and contributed to a lasting cooperation with jurists, which produced this book among other publications.

Clashes between these two disciplines often result from attempts by each one to curtail the other, something which is rather unfavorable to a meaningful common work, and makes such a cooperation far from being easy. Sociologists, when they are not trying to expose the symbolic impact of legal formalisms in reproducing domination, are eager to oppose the reality of social practices to the formalism of law. On their part, jurists currently establish a division of labor between their science and inner expertise, and the subaltern work left to sociologists, of observing the mores or the social uses of law. The kind of multidisciplinary juxtaposition of viewpoints that public tenders promote among researchers does not easily overcome the tensions between sociology and law.

Because of a former experience with sociology and economics, between which comprehensive cooperation created the "convention theory" trend - sometimes called sociology of conventions - (Dupuy et all 1989, Eymard-Duvernay 2006, Orléan 2006 [1994], Salais \& Thévenot 1986) ${ }^{1}$, I looked for a "dialogue between law and sociology that would be rigorous enough to come back to the fundamental operations and categories of each discipline" (Thévenot 1992, 2006 chap. 6). The research program on which this collection of articles is based expanded such a way of cooperating, as shown by its three initiators' introduction (Champeil-Desplats, Porta \& Thévenot). In this article, I will refer to a sociological trend that proved to be favorable to such a demanding cooperation. It goes back to a conceptual shift from the usual notion of 
social norm and led to the analysis of "conventions" that normatively govern the uncertain coordination of actions "put to the test" in concrete situations. Form-giving operations - or "investments in forms" - are needed for the implementation of these conventions. The properly formatted environment supports the normative convention of coordination as long as it "qualifies" for it. A further extension reworked the notion of personal identity that is required to be involved in coordination with others, and conform to collective normativity. A dynamic personal identity was conceived as the composite result of multiple overlapping personal modes of engaging that do not coordinate with others but with oneself from one moment to the next. Coordination with others builds on such personal engagements which broaden the notion of normativity and its modes.

\section{Relating normativity to the forms that regulate the coordination of actions}

4 As conceived by sociologists, the social norm is broader than the legal norm. The concept encompasses explicit as well as implicit rules of conduct. It can even extend to ordinary ways of doing things, included in the wide-ranging term of "social practices". What-engages is related to "values", "beliefs", habits or "habitus". Shared by the members of a community, social norms are enforced through "social control" and not simply institutional control.

5 A sociological trend, referred to as "French pragmatic sociology" because of its concern for situated action, helped renew the approach to normativity by setting it into the broader question of the uncertain coordination of actions, of the forms that give it some conventional guarantee, of the tests and judgments that settle disputes. Here, I will underline the steps that contributed to a dialogue and a cooperation with jurists, and identify common fundamental issues.

\section{Addressing normativity through form-giving operations}

One initial investigation explains the subsequent avenue or research. Its object was the process of "codifying" surveys questionnaires through so-called "codes", classifications that allow to attribute a number to each answer and produce statistical data. The statisticians' vocabulary, visibly borrowed from the jurists' one, encourages drawing parallels between the basic methods of the two disciplines (see the introduction by Champeil-Desplats, Porta, and Thévenot: "A cooperative and transversal research experience between the law and social sciences"). The parallel was elaborated when the statistician became a sociologist and broadened his subject to conceptualize "social coding" (Thévenot 1983, 2016) and "investments in forms" (Thévenot 1984, 1986). These costly investments set up categories, rules, methods, customs, or other conventional and material forms that, in return, favor a coordination of actions and the limitation of its uncertainty. The idea came after observing that every mode of normativity can only be enforced if the environment in which it is implemented is properly formatted. A conceptual continuity between normativity and formatting was thus established.

7 The sociological interest in classification processes (Thévenot 1979) dates back to Émile Durkheim and Marcel Mauss (Durkheim \& Mauss 1971 [1903], 2009 [1903]), and 
continued on with Pierre Bourdieu and Luc Boltanski (Bourdieu \& Boltanski 1975). The multidisciplinary trend of Sciences and Technology Studies introduced in the social sciences a stronger concern with materiality (Latour 1983), while Michel Foucault's work on Les mots et les choses (Foucault 1966, 1970) had previously developed an historical outlook on the épistémès that govern the ways of bringing things together in knowledge formation. These various influences met in Alain Desrosières's first historical works on classifications (1987 [1977]) and my own sociological analyses on classifying processes (Thévenot 1979), as well as our subsequent joint publications (Desrosières \& Thévenot 1979, 1988). Another influence on the concept of "investments in forms" came from economics, as shown by the notion of investment that involves both a costly sacrifice and a profitable return. The collaboration with François EymardDuvernay (Eymard-Duvernay 1986, 1987a, 1987b, Eymard-Duvernay \& Thévenot 1986) strengthened this relation with institutional economics, and contributed to the creation of the so-called "Convention theory" trend.

\section{Qualifying facts for the realist test}

Jurists might grasp more easily that sociologists the notion of "investment in form" because they are aware of the performative aspect of forms. As early as the 1986 publication, a dialogue about this notion gathered sociologists, economists, and jurists around Antoine Lyon-Caen and Antoine Jammeaud. The main idea of the notion of investment in form - that normativity requires the formatting of the situation to be implemented - resonates with the judicial technique of "qualification". The "facts" that are taken into account are not simply selected in order to fall within such a norm, but they are also formatted to qualify for the implementation of the norm, so that their relevance to the judgment makes them evidentiary ${ }^{2}$.

The term "qualification" was used by sociologists and economists to refer to labor skill and its formatting by collective agreements on its classification. The history of social classifications and categories revealed the impact this institutional format had on statistical and social classifications (Desrosières 1985). At the center of the "Economies of worth" paradigm is a broader endorsement of the term (Boltanski \& Thévenot 1987, 1991, 2006). This foundation of the so-called French "Pragmatic sociology" highlights the "qualification test" of the human world and its environment that back up, in the course of criticisms and justifications, the assertion that certain conventional formats contribute to the common good ("worth"), thus increasing their coordination power, and thereby possible domination. The plurality of "orders of worth" that aspire to the common good explains how vehement the critics grounded in one order against another are. It also makes clear that compromises between orders of worth are needed within a pluralist community ${ }^{3}$.

\section{The plurality of conventional orders of justifications that refer to the common good : social, economic, legal}

10 The differentiation of orders of justification, which each refer to the common good, provided a second fertile ground for exchange with Antoine Lyon-Caen and young jurists who were trained under his guidance (Lyon-Caen \& Lokiec 2005), as well as Sheldon Leader and Adalberto Perulli (Lyon-Caen \& Perulli 2010). Such an exchange 
was sustained and consolidated by the creation of an organization headed by Antoine Lyon-Caen and led by Joëlle Affichard, the "International Institute of Paris La Défense", renamed "International Institute for Comparative Studies" after it changed location (see the introduction by Champeil-Desplats, Porta \& Thévenot). With Lyon-Caen, a dialogue about comparisons between orders of worth and fundamental rights, as well as between ordinary judgment and legal judgment, was initiated. In the collective book Public services and fundamental rights in the European construction (Lyon-Caen \& ChampeilDesplats 2001), the distinction between orders of justification for the common good ("worth") helped clarifying the debates around market competition. Civic worth supports solidarity measures to fight against inequalities and promote equal access one of the principles of French public service. In various countries, such equal access will take the form of tariff equalization, universal service, equal servicing throughout the entire territory, accessibility that necessitates particular attention to disabilities (Denmark, Great Britain). European normative texts are influenced by the idea that market competition is also a justification principle, often to the expense of other principles or rights that would only exceptionally outweigh the principle of market competition. This question is more confusing when market competition coordination is designed as a law of nature or some neutral technique, and not as an order of worth that other orders of worth can oppose in a democratic critical pluralism. Some remarks made by judges tasked with interpreting these documents sometimes go in this direction (Thévenot 2001).

11 The distinction between orders of worth does not merely question the dominant position of the market worth. It also clarifies its higher hierarchical position when other orders of worth or rights are reduced to certifiable properties of goods and services. The political debate on the plurality of orders of worth or fundamental rights aiming at the common good is reduced to consumers' individual choices between goods and services the certified qualities of which are assumed to guarantee their conformity to fundamental rights (Thévenot 2018). A transnational "government" by voluntary certification standards fosters modes of normativity that bypass nation states. It transforms fundamental rights when introducing these rights into the standard (see the contribution of Cheyns and Thévenot in this book).

With Sheldon Leader, the exchange delved into justification orders in judgments. Relying on common case law, he proposed a three-faced pattern - "civil" that relates to individual rights, "consensual" that stems from the consent of contracting parties, "functional" that is oriented towards the goals of the organization - which are in conflict and gear judicial justifications (Leader 2000, 2005). This three-part distinction led Leader to a critical approach of certain normative patterns in which the "functional logic of corporations", or the logic of "agreement between contracting parties" trumps the logic of "fundamental rights" (Leader 2009, 2010). He thus deals with agreements between corporations and States, or private agreements between corporations, and analyzes their consequences on how fundamental rights are taken into account and on the plight of the most disadvantaged (Leader 2018). 


\section{What engages : from personal engagements to collective commitments following grammars of communicating and differing}

13 Social or judicial normativity is particularly apparent in public disagreements or trials that are indicative of a failure to coordinate within a community. But one needs to put these moments of public disagreement into perspective, given what makes people more intimately engaged, and which, when affected, harms them. Moments of public dispute necessitate an operation prior to implementing the norm, an operation through which individuals transform the trouble they experienced into a grievance, a wrong, a criticism, or a cause articulated in an acceptable manner for the test of a public judgment. To understand the required chain of transformations it undergoes until the final judgment on offense, it is important to analyze the trouble in its first stage, remote from the well-argued formulation in a claim for justice. Having penetrated the most personal ways of engaging with the world, the sociology of conventions and engagements follows the transformations of concerns based on personal modes of normativity into their public formulation that build commonality and difference according to various "grammars".

\section{Below the level of social and legal norms : modes of engagements with the environment}

To conform to norms, a kind of temporal continuity is needed that the notion of personal identity grasps. Varying with disciplinary trends, each conception of identity is congruent with the mode of coordination with others that the discipline favours: contractual, market, social. ${ }^{4}$ In law, a strong individual will is assumed for the person to enter into agreements. In economics, the well-established identity is conceived as an individual interest and required for optimizing calculation and market coordination. In sociology, identity is no less firm, still reinforced by its collective nature. Social identity is often rooted in bodies collectively shaped by cultures or habitus, ready to coordinate in shared social practices. In contrast, some sociologists have developed a labile individual identity that would only come from others, or that would depend on the individual's shifting choice between a range of multiple identity options. If the first conceptions of identity are too solid, the last ones jeopardize the minimum requirement of continuity needed to comply with normativity.

Some philosophers have challenged the most stable, if not substantial, conceptions of identity. Hume conceived "a bundle or collection of different perceptions, which succeeds each other with an inconceivable rapidity, and are in a perpetual flux and movement" (Hume 1978[1740], I,IV,VI, p. 252). Such a moving flow dissolves any form. However, the role of invested forms in coordinating actions with others prompted us to consider them in coordination with ourselves. The pragmatic approach to personal identity I propose views it as the dynamic result of an uncertain coordination with oneself, from one situation to another, in which forms invested personally have a significant place. Relating this dynamic continuity with the forms that serve the person to self-identify oneself, in the persistence of one's being, the notion of engagement "brings to light elementary kinds of normativity that govern personal relations with 
the world" (Thévenot 1997, p. 210). Being at one's convenience, these engagements are more intimately personal that the ones backed on conventions such as customs or rules. More than just an activity, engagement involves a valuable correspondence between the person and oneself, which is ensured by a kind of relationship to the surrounding world that offers guarantees of this continuity. Thus, familiar engagement aims at a good - familiar ease - which is far from the communicable generality of a fundamental right or a common good, or even of an individual interest that is formatted for negotiation between stakeholders. This familiar engagement relies on a kind of formatting or arranging of the material environment "to hand" that ensures the engagement through personal accommodation and personal reference points. Rather than a simple routine set once and for all, this familiar mode of engagement like all the others - involves moments of doubt or trial and error in establishing or challenging the reference points to which it cannot be reduced. Because each engagement sustains coordination with oneself, it gives consistence to the person (Thévenot 2009, 2014) and renews the way to approach personal identity (Luhatakallio \& Tavory 2018).

More than a decade after this conceptualization of a dynamic personal identity based on a plurality of regimes of engagements (Thévenot 1990, 1997, 2006, 2009), the philosopher Charles Larmore proposed an approach to personal identity also based on the notion of "engagement" [in French] (Larmore 2004, 2010). He writes that "it is an essentially practical - or more precisely normative - relationship to oneself, in so far as to commit oneself means obliging oneself to respect what the commitment gives us reason to do" (2004, p. 9), a relationship that can remain "implicit" (p. 118). He also views personal identity as the result of the combination of these various engagements I used the image of overlapping and tiling a roof while Larmore refers to the image of weaving a rope - each of them contributing to a part of the continuity of the self, without any of them being durable enough to constitute an identity link on their own. Unlike Larmore, however, the plurality of regimes of engagement does not only specifies the kinds of good to which we commit ourselves, but also the formatted material environment that provides "pledges" - gages in French - as security for the fulfillment of this engagement - the reason for our choice to keep "engaging" in English, as materially "engaging the gears", rather than "commitment", more usual, that Larmore chose in the English translation of his first publication in French (Larmore 2010).

While dealing with what is intimately personal, the concept of engagement remains sociological. It refers to modes of relating to oneself via the world that we can understand when interpreting someone else's behavior although the expected good is not a common good nor even a shared one, and the details of his or her conduct might not be intelligible - which hinders communication and coordination. "Interest" or "habitus" are categories that imply two, among others, of these regimes of engagement. The individual's engagement in a voluntary plan, which is currently presupposed of the legal subject, is based on only one of these engagements. These various personal engagements involving the surrounding world as a support do not rely on a common conventional format. When affected, they cause uneasiness, trouble or indignation that need to have their format changed to claim justice. The costs and difficulties of transforming personal engagements into common normative forms often cause frustration and bitterness towards public debate or litigation, as shown by several papers of this collection. This is the reason why we need to carefully consider these personal engagements that are usually left behind by norms, whether social or 
legal. Jurists do not problematize the distance between norms and personal engagements, except in terms of "mobilization" of the legal system, an operation that takes for granted the format of the judicial claim.

\section{The plurality of overlapping engagements which ensure the continuity of a dynamic personal identity}

This new development clarifies the dialogue with jurists. Law currently assumes a regime of engagement in an individual plan that sustains the autonomous and responsible individual's will and permits its projection in the future and the possibility of contracting. An environment captured through a functional format ensures such an engagement. Jean Carbonnier observes that "this constant of dogmatic law distresses sociologists : loathing the idea of conceiving a process where willingness is more of a glimmer than a light, where materiality is essential - this materiality so feared by jurists because it makes us forget about law" (Carbonnier 1988, p. 296). He mentions the exception of the hotel luggage drop off which engages us through a "done-deed ["actefait"], like a mechanical agreement contracted between the room and the suitcase" (id.). Alain Cottereau, in his analysis of the customary "law" of labour relationships, as exhibited notably in labour courts ("prud'hommes"), also highlights "validations that refuse to be reduced to voluntary schemes" (Cottereau 1988).

This "mechanical agreement" mentioned by Carbonnier rests upon an engagement that strongly differs from the plan and needs to be more precisely characterized than with the vague term of "informal" and the too-easy opposition to legal formalism. The familiar engagement is a personal coordination with oneself resting upon an habituation that creates, not the projection of a will into the future but the kind of confidence that lies in a familiarly accommodated environment (see the table below). This engagement supports the ease guaranteed by surroundings that are grasped by idiosyncratic indices and conveniently accommodated through a former habituation. In contrast with the cases that Carbonnier and Cottereau studied, which focused on behaviors that others easily identify, the familiar engagement often resists to coordinating with others because indices are too personal to be understood by someone else. To coordinate several persons' engagements in familiarity, intimate acquaintance with the other is required. In contrast, thanks to the functional format by which the environment is grasped, the engagement by plan is more likely to coordination between several individuals.

Transforming the damage of an impacted familiar engagement into the format of a legal claim is a heavy task and meets several obstacles as shown by many contributions to this publication (Affichard, Aka Larmarche, Cheyns and Thévenot, Pecot, Vergel). Mathias Pécot studies the "territorial" anchoring of marginal urban asentamientos in Guayaquil, and highlights the transformations that would be needed to reach the format of the law. He writes that the city's production "is accompanied by transitions from normativity formats close to the habitat, the domestic life, the familiarity with the surrounding" to "more formalized formats and facilities" (Pécot, in this volume). Such transformations prepare for the transition to law and the "guaranteed city" (Breviglieri 2018). Not only local but also personal habituations format the habitat. At the most personal level, inhabitants are engaged in familiarity, and coordination with others is not easy as shown by research on cohabiting (Breviglieri and Pattaroni 2005, Charles 2012, Thévenot 2017b). The "waste" that the inhabitant 
produces is a good example of the architecture of what engages and of various modes and equipment of normativity, from the familiar engagement based on personal habits to more or less formalized collective kinds of normativity, including judicial ones. Between the familiar way of dealing with the rubbish of one's personal activity and the way household garbage is collected in appropriate containers, several "investments in forms" sustain a whole normative architecture. Such is the case of the "botadero", opensky piles of waste that, in the asentamientos neighbourhood, conforms to a local and customary kind of normativity. Pécot lists the series of both material and normative transformations required to transition into $\mathrm{law}^{5}$.

\section{The dynamics of the regime of engagement : closing vs. opening the eyes}

21 As pointed to by the term "regime", engagement has a dynamics. It includes two stances which correspond to two contrasted facets of the engagement, in the pursuit of the desired good (see the table below). The first stance, "closing the eyes", is one of quietude grounded in reference points that are relied upon. In the second stance, "opening the eyes", one of inquietude, enduring doubt is opening up to what the reference points sacrifice and caused by the flux of life. From my first research on the "paradox of social coding", caught in between fuzziness and rigor, the tension between these two facets stroke me (Thévenot 1979). Economies of coordination costs stem from the fact that users rely on the conventional reference point provided by the code. Still, when coding questionnaires, users are led to doubt these reference points when they open themselves to the discrepancies between answers that are sacrificed for the sake of the coded form. Similarly, the letter of the convention is at the heart of the legal system or institutions. Yet, it may also be critically doubted as a legal fiction. Jurists and sociologists often fail to conceptualize this dualism of conventional forms, and make a symmetrical reduction. For the first ones, the letter of the law prevails while the second ones unveil the illusionary character of formality, with regard to the reality of practices.

The following table compares three regimes of personal engagement upon which different kinds of normativity are built: customary, contractual, or grounded in conceptions of the common good. They can find a place in law, not without transformation. The first characteristic of each engagement concerns the ability and power that the engagement assures. It contributes to the consistency of the person engaged, from one situation to another. Follows the desired good, and then the preparation or formatting that reality undergoes to support the engagement. After characterizing the quietude and inquietude stances, the last lines of the table bring out the difference between the relation with another engaged human being, and his or her reification as an element of the environment involved in one's own engagement.

\begin{tabular}{|l|l|l|l|}
\hline REGIME & & & $\begin{array}{l}\text { public justification } \\
\text { for the common } \\
\text { good }\end{array}$ \\
\hline
\end{tabular}




\begin{tabular}{|c|c|c|c|}
\hline Invested power & $\begin{array}{l}\text { the easiness coming } \\
\text { from } \\
\text { habituation }\end{array}$ & $\begin{array}{l}\text { the autonomy of the self- } \\
\text { projected in the future }\end{array}$ & $\begin{array}{l}\text { worth qualifying the } \\
\text { common good. }\end{array}$ \\
\hline Engaged good & ease & $\begin{array}{l}\text { self-projection through } \\
\text { individual plans or } \\
\text { projects }\end{array}$ & $\begin{array}{l}\text { participation in the } \\
\text { common good }\end{array}$ \\
\hline Engaged reality & $\begin{array}{l}\text { personally } \\
\text { accommodated }\end{array}$ & functionally grasped & $\begin{array}{l}\text { qualified for the } \\
\text { common good }\end{array}$ \\
\hline $\begin{array}{l}\text { The two facets } \\
\text { d1. Quietude } \\
\text { d2. Inquietude }\end{array}$ & $\begin{array}{l}\text { routine/ } \\
\text { groping }\end{array}$ & $\begin{array}{l}\text { objective of the plan/ } \\
\text { irresolute }\end{array}$ & $\begin{array}{l}\text { justified/ } \\
\text { critical }\end{array}$ \\
\hline $\begin{array}{l}\text { Helping the other in } \\
\text { her/his engagement }\end{array}$ & $\begin{array}{l}\text { taking care, } \\
\text { demonstrating } \\
\text { solicitude }\end{array}$ & $\begin{array}{l}\text { strengthening the will, } \\
\text { giving confidence in one's } \\
\text { project }\end{array}$ & $\begin{array}{l}\text { preparing for the } \\
\text { trial of public } \\
\text { qualification }\end{array}$ \\
\hline Reifying the other & $\begin{array}{l}\text { make the other your } \\
\text { personal thing }\end{array}$ & $\begin{array}{l}\text { make the other } \\
\text { instrumental to one's } \\
\text { plan }\end{array}$ & $\begin{array}{l}\text { reduce the object to a } \\
\text { qualified object. }\end{array}$ \\
\hline
\end{tabular}

\section{Framing disputes : grammars to communicate and differ}

The notion of engagement was conceived to characterize a personal coordination that operates more with one-self, from one situation to another, thanks to an appropriate material environment. Without being collective or "social" in the collective sense, every regime of engagement can be recognized by the other. It is thus "social" in a broader sense of the word. Starting from the personal level, without assuming a readymade collective, gives a full account of the necessary transformations to go from a coordination with one self to a coordination with the other. This coordination with others requires commonality which is also needed to differ in a dispute.

Law offers the most formal tools to regulate disputes proceedings and resolutions. These disputes play an important role in sustaining the community and its politics. The "orders of worth" model deals with justifications that each aspire to the common good, and opened up to a sociology of disputes, either internal to an order of worth, or from an order to another, based on the modeling of a shared sense of what is just and what is unjust (Boltanski \& Thévenot 1987, 1991, 2006). The concept of a "compromise" between orders of worth deals with the search of an appeasement of critical tensions between justifications grounded into different orders of worth. In this model, criticisms and justifications are directly formulated in the common good format. Such a requirement to be heard involves a significant transformation of what engages in the most personal way, particularly in the familiar engagement with things and places that we use and we inhabit. Another step has made the most of a comparative perspective, first between France and the USA (Lamont \& Thévenot 2000), then Russia (Thévenot 2017a, 2019), in order to identify various "grammars" of communicating and differing (Thévenot 2015a). These grammars distinguish ways of communicating a plurality of 
voices, of specifying differences between them to be taken into account, and of integrating them in the construction of one community's good (Moody \& Thévenot 2000, Thévenot \& Lamont 2000, Thévenot 2014).

The project is to renew the approach to politics, by addressing it from its practical requirements when living together within a community. Without going directly to the most formal devices of institutions, rights, elective, or decision-making procedures, this approach considers political communities and their government from a view on ways of doing things in the world with others. Although communities vary in their cultural and historical backgrounds, our project is to make them comparable in one respect, which is possible thanks to the structural constraints of communicating and differing that their members have to cope with. Through communication (in the sense of making issues common), individuals take part in the community building by transforming everything that personally and locally affects them to make it communicable. The dispute is regulated by privileging certain differences while sacrificing others. Through the composition (of the good of the community), individuals deal with the revealed differences to integrate them in some way. Composing means making up a whole from differences.

This analytical framework allowed to characterize the pragmatic dispute methods, according to a liberal grammar of interests that is clearly different from the grammar of multiple orders of worth referring to the common good. Individuals take part in a legitimate dispute, without directly referencing a substantial conception of the common good, but by expressing in a certain format an individual choice. We could talk about a "liberal grammar of individual interests" (Eranti 2017, 2018) even though in economic, social, and political sciences, naturalizing this "interest" category prevents identifying the requirements of transformation necessary to this grammar. The act of communication asks for sacrifices that are not apparent when it is mostly the liberty of the individual that is highlighted. According to this liberal grammar of individual interests, communicating supposes that the individual rises in public as an individual choosing autonomously among options that other individuals accept. The individuals project themselves in these options when they choose them, in such a way that they already need the engagement in plan format with the additional requirement that each individual can identify all options-plans to be able to differ and negotiate with others. What affects the person in their most intimate attachments - based upon a familiar engagement - and their most rooted beliefs must be transformed, not without some cost, in order to espouse the options format that can be understood and chosen by every other choosing individual of the liberal public. Composition acts through "negotiation" between these choosing individuals. Emotionally showing a strong, intimate, and personal attachment in public disqualifies a voice for it inconveniences the autonomy of other individuals making their own independent choices.

In the conversation with jurists, it is important to specify the pragmatic requirements of the liberal grammar, which are different from the orders of worth grammar, especially since jurists pay attention to constitutional and normative pluralism, as do those involved in this book. As we previously saw, the format of individual will that law prefers requires of the individuals to project their will, just as in the engagement in plan. This requirement has also to be satisfied for he or she to be part of the public as set out in the liberal grammar, by voicing his autonomous choice for a preferred option. This grammar also bears its hallmark on how individual rights are formulated, even as a 
number of right are intended to protect the engagement for common goods that is supported by the grammar of multiple orders of worth. Transitioning towards law, which a number of contributions in this book touch upon, cannot occur without costly transformations and sacrifices, as readers will see. Transnational government by standards that overhaul nationals and international rights regimes creates a "standardizing liberalism" ("libéralisme normalisateur" : Thévenot 1997) and unfolds in a "multistakeholder" construction of the community that is itself based upon the liberal matrix (Cheyns 2011, 2014, Cheyns \& Riisgard 2014, Cheyns \& Thévenot in this book). Similarly, the Free Prior Informed Consent formula is conforming with the liberal grammar. Favored for a long time in international law, this formula now encounters other rights formulas, in the definition of the "rights of the peoples", that cannot fit unhindered in the liberal matrix. The notion of informed and free consent is itself promoted in a broadened version to include the consent of the peoples (Colchester 2002, and in this book, the interview with Marcus Colchester, as well as the contribution of Cheyns \& Thévenot).

\section{Conclusion} the name of social practices, the operation of form-giving or formatting, its costs, sacrifices, and expected returns were put at the center of this new sociological orientation. From the statistical "codes" to "social coding", the analysis extended to all forms that contribute to coordination in spite of its uncertainty. Initially rooted in statistics, where forms are strengthened by methods and technical equipment, and where reality can only be "recorded" if previously formatted, this analysis borrowed the judicial notion of facts "qualification" to conceptualize the idea that every norm is only operative upon a selected and formatted reality. The categories of trial, test and judgment, which hold a crucial place in this sociology, are also defined in relation with the format of what can be evidentiary, in continuity with the notion of qualification. Beyond the qualification of facts taken into account in the judgment, this analysis promoted a dialogue with jurists on the formatting and preparation of the world that is needed by the "implementation" of law (Porta 2008, Stavo-Debauge 2005, 2008).

30 A second common ground with jurists came from the shared idea that should be taken into account more diverse kinds of normativity than the ones widely accepted in the two disciplines. The internationalization of law, the interlocking and continuous rearrangement of social, economic, and legal kinds of normativity force the jurist to specify his categories, and not simply distinguish "soft" ones, in standardization notably, from others. Thanks to this opening up to pluralism, the analysis of the various ways different kinds of normativity meet together can be more in-depth. The 
way one norm shifts, from one order of normativity to another, does not leave it unchanged. Government by standard transforms judicial, political, ethical and even religious kinds of normativity to format them as certifiable qualities of goods or services (Thévenot 2015). The shifting and transforming of religious norms in a certification standard creates an hybrid result that in return affects religious normativity, reinforcing its fundamentalist and literalist modality (Florence BergeaudBlackler 2017).

31 Finally, searching below collective kinds of normativity to identify personal engagements that lack public legitimacy, this sociological orientation brings light on an often obscure aspect of the work of justification or justice. It spells out the requirements and costs of taking part in a public dispute or a trial, pointing to the need to transform personal troubles, and to the consequences of this transformation on the cause publicly championed. It clarifies the oppressions and frustrations that plaintiffs feel because public formats have proved to be improper to make room for goods and ills, that affect their personal engagements (Cardoso de Oliveira 2005, Charles 2015). By distinguishing grammars of communicating and differing that unequally make room for transformed personal engagements, it sheds lights on the dispute resolution mechanisms that aspire to come closer to personal concerns and engagements, such as small claims courts (Cardoso de Oliveira 2005) or mediation (Battistoni 2014). A sociology of what engages, both personally and in common, favours an alliance with law scholars that is less limited than the previous one based on confusing social with collective (Thévenot 2008).

\section{BIBLIOGRAPHY}

Battistoni, Eric, 2014, "Quand justice est rendue aux perdants : l'enrôlement social des surendettés", Pensée plurielle n 37, pp. 95 à 110.

Bergeaud-Blackler Florence, 2017, Le marché halal ou l'invention d'une tradition, Paris, Seuil.

Bessy, C., 2015, L'organisation des activités des avocats. Entre monopole et marché, Paris, LGDJ.

Boltanski, L., Thévenot, L., 1987, Les économies de la grandeur, Paris, Presses Universitaires de France et Centre d'Etude de l'Emploi.

Boltanski, L., Thévenot, L., 1991, De la justification. Les économies de la grandeur, Paris, Gallimard.

Boltanski, L., Thévenot, L., 2006, On justification. Economies of worth, Princeton, Princeton University Press (transl. by Catherine Porter, 1st French edition 1991).

Bourdieu, P., Boltanski, L., 1975, "Le titre et le poste : rapports entre le système de production et le système de reproduction", Actes de la recherche en science sociales, 1(2), pp. 95-107.

Breviglieri, M., 2013, "Une brèche critique dans la 'ville garantie' ? Espaces intercalaires et architectures d'usage" in Cogato Lanza Elena, Pattaroni Luca, Piraud Mischa, Tirone Barbara (eds), De la différence urbaine. Le quartier des Grottes, Genève : MétisPresses, pp. 213-236. 
Breviglieri Marc et Luca Pattaroni, 2005, «Le souci de propriété. Vie privée et déclin du militantisme dans un squat genevois », dans Bernard Haumont et Alain Morel (éd.), La société des voisins, Paris, Éditions de la Maison des sciences de l'homme, p. 275-289.

Carbonnier, J., 1988, Flexible droit, Paris, LGDJ (6ème édition).

Cardoso de Oliveira Luís Roberto, 2005, Droit légal et insulte morale. Dilemmes de la citoyenneté au Brésil, au Québec et aux États-Unis, Laval, Les Presses de l'Université Laval.

Charles, Julien, 2015, Une participation sans condition? Une sociologie des épreuves de l'engouement participatif, Paris, Desclée de Brouwer.

Cheyns, Emmanuelle, 2011, "Multi-stakeholder initiatives for sustainable agriculture : limits of the 'Inclusiveness' paradigm", in Ponte, Stefano, Gibbon, Peter and Vestergaard Jakob (eds.), Governing through Standards. Origins, Drivers and Limitations, London, Palgrave, pp. 210-235.

Cheyns, Emmanuelle, 2014, "Making 'minority voices' heard in transnational roundtables : The role of local NGOs in reintroducing justice and attachments", Agriculture and Human Values, vol 31 $\mathrm{n}^{\circ} 3$, pp. 439-453.

Cheyns Emannuelle and Riisgaard Lone, 2014, "Introduction to the symposium". The exercise of power through multi-stakeholder initiatives for sustainable agriculture and its inclusion and exclusion outcomes, Agriculture and Human Values, vol 31 n 3, pp. 409-423.

Colchester, Marcus, 2002, "Indigenous rights and the collective conscious", Anthropology Today, 18(1), pp. 1-3.

Cottereau, A., 1988, "Justice et injustice ordinaire sur les lieux de travail d'après les audiences prud'homales (1806-1866)", Le Mouvement Social, n 141, oct-déc., pp. 25-59.

Desrosières, A., 1985, "Histoires de formes : statistiques et sciences sociales avant 1940", Revue française de sociologie, vol. 26, $\mathrm{n}^{\circ} 2$, mars-avril, pp. 277-310.

Desrosières, A., 1987 [1977], "Eléments pour l'histoire des nomenclatures socioprofessionnelles", in Affichard, Joëlle (ed.) Pour une histoire de la statistique, t. 1, Paris, Insee \& Economica, pp. 155-231 (première édition : Insee 1977).

Desrosières, A., Thévenot, L., 1979, "Les mots et les chiffres : les nomenclatures socioprofessionnelles", Economie et statistique, $\mathrm{n}^{\circ} 110$, avril, pp. 49-65.

Desrosières, A., Thévenot, L., 1988, Les catégories socioprofessionnelles, Paris, La Découverte.

Diaz-Bone Rainer \& Favereau Olivier (Eds.), 2019, "Markets, Organizations, and Law Perspectives of Convention Theory on Economic Practices and Structures", Historical Social Research, 40(1).

Dupuy, J.-P. et alii, 1989, Revue économique, numéro spécial L'économie des conventions, vol. 40 n², mars.

Durkheim, E., Mauss, M., 1971 [1903], "De quelques formes primitives de classification. Contribution à l'étude des représentations collectives" (Année sociologique, 6., 1903) republié dans Mauss, M., Essais de sociologie, Paris, Ed. de Minuit, Col. Points.

Durkheim, E., Mauss, M., 2009 [1970], Primitives classifications, London, Routledge (translated with an introduction by Rodney Needjam).

Eranti, Veikko, 2017, "Re-visiting NIMBY : From conflicting interests to conflicting valuations", The Sociological Review, 65 (2), 285-301. 
Eranti, Veikko, 2018, "Engagements, grammars, and the public : from the liberal grammar to individual interests", European Journal of Cultural and Political Sociology, 5(1-2) Special issue on "Politics of Engagements", pp. 42-65.

Eymard-Duvernay, F., 1986, "La qualification des produits", in Salais, R., Thévenot, L., (eds.), Le travail. Marché, règles, conventions, Paris, INSEE-Economica, pp. 239-247.

Eymard-Duvernay, F., 1987a, "Droit du travail et lois économiques : quelques éléments d'analyse", Travail et Emploi, n³3, sept., pp. 9-14.

Eymard-Duvernay, F., 1987b, "Introduction : les entreprises et leurs modèles" in Entreprise et produit, Paris, PUF (Cahiers du Centre d'Etudes de l'Emploi 30), p. V-XXII.

Eymard-Duvernay, F., (ed.), 2006, L'économie des conventions, Paris, La Découverte, tome I Méthodes et résultats, tome II Développements, Paris, La Découverte.

Eymard-Duvernay, F., Thévenot, L., 1986, "L'économiste et son modèle", in Thévenot, L., (ed.), Conventions économiques, Paris, Centre d'Etudes de l'Emploi - Presses Universitaires de France, pp. 129-150.

Favereau, Olivier (ed.) 2010. Les avocats, entre ordre professionnel et ordre marchand. Paris : Lextenso Editions/Gazette du Paris.

Foucault, M., 1966, Les mots et les choses, Paris, Gallimard.

Foucault, M., 1970, The order of things : an archaeology of the human sciences, New York, Pantheon Books (first French edition in 1966).

Hume, D., 1978 [1740], A Treatise of Human Nature, Oxford, Clarendon Press (edition with the index of L.A. Selby-Bigge, 1888, revised by P.H. Nidditch from the original edition of 1740).

Lamont, M., Thévenot, L. (eds.), 2000, Rethinking Comparative Cultural Sociology : Repertoires of Evaluation in France and the United States, Cambridge, Cambridge University Press.

Larmore, Charles, 2004, Les pratiques du moi, Paris, PUF.

Larmore, Charles, 2010, The Practices of the Self, Chicago, University of Chicago Press (translated by Sharon Bowman).

Latour, B., 1983, Les microbes : guerre et paix suivi de Irréductions, Paris, Ed. Métailié.

Leader, Sheldon, 2000, "Three faces of justice and the management of change", Modern Law Review, vol. 6, january, pp. 55-83.

Leader, Sheldon, 2005, "Two ways of linking economic activity to human rights" , International Social Science Journal, 2005, n 185, pp. 541-550.

Leader, Sheldon, 2009, "The Collateral Protection of Rights in a Global Economy", New York Law School Law Review, 53(4), pp. 805-814.

Leader, Sheldon, 2010, "Labour Rights in the World Economy", in Lyon-Caen Antoine et Perulli Adalberto (dir.), 2010, Valutare il diritto del lavoro. Evaluer le droit du travail. Evaluate labour law, Padova, Cedam, pp. 113-122.

Leader, Sheldon, 2018, "Institutional Variety, Civil Society and Basic Rights", in Jeammaud, Antoine, Le Friant, Martine, Lokiec, Pascal, Wolmark Cyril (eds.), A droit ouvert, Paris Dalloz, pp. 532-544.

Luhtakallio, Eeva 2012. Practicing Democracy. Activism and Politics in France and Finland. Basingstoke : Palgrave Macmillan. 
Luhtakallio, Eeva \& Tavory Iddo, 2018, "Patterns of engagement : Identities and social movement organizations in Finland and Malawi", Theory and Society, 47 (2) :151-174.

Lyon-Caen, Antoine, Champeil-Desplat, Véronique, (eds.), 2001, Services publics et droits fondamentaux dans la construction européenne, Paris, Dalloz.

Lyon-Caen A., Lokiec P. (eds.), 2005, Droits fondamentaux et droit social, Paris, Dalloz.

Lyon-Caen Antoine et Perulli Adalberto (dir.), 2010, Valutare il diritto del lavoro. Evaluer le droit du travail. Evaluate labour law, Padova, Cedam.

Moody, M. \& Thévenot, L, 2000, "Comparing Models of Strategy, Interests, and the Public Good in French and American Environmental Disputes", in Lamont Michèle et Thévenot Laurent (eds.), Rethinking comparative cultural sociology : Repertoires of Evaluation in France and the United States, Cambridge, Cambridge University Press, pp. 273-306.

Normand, R., 2016a, The Changing Epistemic Governance of European Education. The Fabrication of the Homo Academicus Europeanus? Basel, Switzerland : Springer.

Normand, R., 2016b "« What works ? " : From health to education, the shaping of the European policy of evidence" in Trimmer Karen (ed.), Political Pressures on Educational and Social Research. International perspectives, London, Routledge, pp. 25-40.

Orléan, André (dir.) 2004 [1994], Analyse économique des conventions, Paris, PUF, collection Quadrige ( $2^{\mathrm{e}}$ édition avec post-face additionnelle de André Orléan ; $1^{\mathrm{e}}$ édition 1994).

Porta, Jérome, 2008, La réalisation du droit communautaire. Essai sur le gouvernement juridique de la diversité, (2 volumes), Ed. L.G.D.J \& Fondation Varenne.

Salais, R. et Thévenot, L. (eds.), 1986, Le travail ; marchés, règles, conventions, Paris, INSEE Economica.

Silva-Castañeda, Laura 2012. A forest of evidence : third-party certification and multiple forms of proof - a case study on oil palm plantations in Indonesia. Agriculture and human values 29 : 361-370.

Stavo-Debauge, J., 2005, "Mobilising statistical powers for action against discriminations : the case of the United Kingdom", International Social Science Journal, 2005, n 183, pp. 43-55.

Stavo-Debauge, J., 2008, "Faut-il s'en remettre aux pouvoirs de la statistique pour agir contre les discriminations et réaliser le droit ? La catégorisation ethnique et raciale en question au Royaume Uni et en France", in Lyon-Caen A. et Perulli, Adalberto (dir.) Efficacia e diritto del lavoro, Padova, Cedam, pp. 163-194.

Thévenot, L., 1979, "Une jeunesse difficile ; Les fonctions sociales du flou et de la rigueur dans les classements, Actes de la recherche en sciences sociales, n²6-27, pp. 3-18.

Thévenot, L., 1983, "L'économie du codage social", Critiques de l'Economie Politique, nº 23-24, pp. 188-222.

Thévenot, L., 1984, "Rules and implements : investment in forms", Social Science Information, vol. $23, \mathrm{n}^{\circ} 1$, pp. 1-45.

Thévenot, L., 1986, "Les investissements de forme", in Thévenot, L. (ed.) Conventions économiques, Paris, PUF (Cahiers du Centre d'Etude de l'Emploi 3), pp. 21-71.

Thévenot, L., 1990, "L'action qui convient", in Pharo, P. et Quéré, L., (éds.), Les formes de l'action, Paris, Ed. de l'EHESS (Raisons pratiques 1), pp. 39-69 (repris dans : Thévenot 2006). 
Thévenot, L., 1992, "Jugements ordinaires et jugement de droit", Annales ESC., nº 6, nov.-déc., pp. 1279-1299.

Thévenot, L., 1997, "Un gouvernement par les normes ; pratiques et politiques des formats d'information", in Conein, B. et Thévenot, L. (dir.), Cognition et information en société, Paris, Ed. de l'EHESS (Raisons Pratiques 8), pp. 205-241.

Thévenot, L., 2001, "Les justifications du service public peuvent-elles contenir le marché ?", in Lyon-Caen, Antoine et Véronique Champeil-Desplat (eds.), Services publics et droits fondamentaux dans la construction européenne, Paris, Dalloz, pp. 127-143.

Thévenot, L, 2006, L'action au pluriel. Sociologie des régimes d'engagement, Paris, La Découverte.

Thévenot, L., 2007, "The plurality of cognitive formats and engagements : moving between the familiar and the public", European Journal of Social Theory, 10(3), pp. 413-427.

Thévenot, L., 2008, "Les sciences économiques et sociales et le droit : quels biens reconnus, pour quelles évaluations ?", in Lyon-Caen A. et Perulli, Adalberto (dir.) Efficacia e diritto del lavoro, Padova, Cedam, pp. 65-97.

Thévenot, L., 2009, "Biens et réalités de la vie en société. Disposition et composition d'engagements pluriels", in Breviglieri, M., Lafaye, C., et Trom, D. (dir.) Compétences critiques et sens de la justice, Paris, Economica, pp. 37-55.

Thévenot, L., 2011, "Pouvoirs en question. La sociologie des régimes d'engagement", SociologieS, http://sociologies.revues.org/index3572.html

Thévenot, L., 2014, "Voicing concern and difference. From public spaces to common-places", European Journal of Cultural and Political Sociology, 1(1) 7-34.

Thévenot, Laurent, 2015a, "Making commonality in the plural, on the basis of binding engagements", in Dumouchel Paul and Gotoh Reiko (eds.), Social Bonds as Freedom : Revising the Dichotomy of the Universal and the Particular, New York, Berghahn, pp. 82-108.

Thévenot, Laurent, 2015b, "Certifying the world. Power infrastructures and practices in economies of conventional forms", in Aspers, Patrick and Nigel Dodd (eds.), Re-Imagining Economic Sociology. Oxford : Oxford University Press, pp. 195-223.

Thévenot, L., 2016, "From Codage social to Economie des conventions : A Thirty Years Perspective on the Analysis of Qualification and Quantification Investments", Historical Social Research, 41(2), pp. 96-117.

Thévenot, L., 2017a, "'Des liens du proche aux lieux du public' : retour sur un programme francorusse pionnier", Revue d'Etudes Comparatives Est-Ouest, 48(3-4) 45-93.

Thévenot, L. (avec la collaboration de Janna Tsinman et Ariane Zambiras), 2017b, "En commun, en différend. Politiques comparées dans l'apprentissage de la vie ensemble en foyer étudiant", Revue d'Etudes Comparatives Est-Ouest, 48(3-4) 7-43.

Thévenot, L., 2018, "Droits et biens pris en compte par les engagements volontaires d'entreprises dans des standards internationaux. La 'sustainable palm oil' certification au regard des plus défavorisés", in Jeammaud, Antoine, Le Friant, Martine, Lokiec, Pascal, Wolmark Cyril (eds.), A droit ouvert, Paris Dalloz, pp. 929-945.

Thévenot, L., 2019, "How does Politics Take Closeness into Account ? Returns from Russia", International Journal of Politics, Culture, and Society (submitted). 
Thévenot, L, and Lamont, M. 2000, "Exploring the French and American polity", in Lamont M. et Thévenot L. (eds.), Rethinking comparative cultural sociology : Repertoires of Evaluation in France and the United States, Cambridge, Cambridge University Press, pp. 307-327.

\section{NOTES}

1. On Convention theory and law, see also: Favereau 2010, Bessy 2015, and the special issue paying homage to François Eymard-Duvernay, directed by Rainer Diaz-Bone \& Olivier Favereau, "Markets, Organizations, and Law - Perspectives of Convention Theory on Economic Practices and Structures" (Diaz-Bone Rainier \& Favereau 2019).

2. The analysis of what is evidentiary became still more important because of the rise in " evidence-based" politics (Normand 2016a, 2016b) and of the expansion of government by standards and measurable objectives that rest upon a narrow format of evidence (SilvaCastaneda 2012).

3. The words "communal" and "community" are used in this text without assuming the way in which the "communal" is created by several people.

4. Similarly, political philosophers establish a "state of nature" to serve the construction of the common good that they promote.

5. "From the sale agreement to the property title; from the tinkered illegal connection to the sacrosanct electricity meter; from the purchase of drinking water from the tanquero - a tanker truck providing daily supply service to the asentamiento - and to the first water bill ; from the latrine to the toilets; from the four prefabricated walls of the Casa Hogar de Cristo to the cement ; from the botadero - the open air discharge point for household waste - to the inscription of the cuadra - the minimum urban planning unit - on a public household waste collection route ; from prepaid mobile phone service to the first cybercafé ; from trici-motorcycles to transport cooperatives, and to alimentadores - shuttles providing a direct connection to the municipal “ metrovia" transport network - via the service of urban transport cooperatives ; from temporary schools to public schools; from dispensario as the first medical care service provided by NGOs or churches to centros de salud linked to the public health system and the IESS (Ecuadorian Social Security Institute) : thousands of operations, exchanges and compromises are involved in the process of consolidating asentamientos" (Pécot, in this collection). 